DOI: 10.20472/IAC.2019.052.009

DJAMEL EDDINE BENAMIER

University Mohamed BOUDIAF of M'Sila, Algeria

\title{
THE REFORM OF THE LOCAL ADMINISTRATION IN ALGERIA BETWEEN ACTUAL CHALLENGES AND FUTURE PROSPECTS
}

\begin{abstract}
:
The local administration in Algeria is currently facing major challenges that have resulted from a number of social, economic and political developments. It has touched on several aspects of our lives. It has focused mainly on the change in society and the economy and the repercussions of globalization, the latest of which is the global economic and financial crisis. The role of these institutions and adapting their work to meet these challenges through reform. This reform process is among the new measures and measures to improve the management and management of local communities and to activate their role for economic and social development on a local scale, where this is done on two levels; the first covers the administrative side, and the second related to the financial side.

In this paper we provide a brief explanation of the reform process, the most important challenges faced by local administration, the prospects for their development and the improvement of their administrative and financial performance to carry out their roles at the level of comprehensive national development and improving citizens' lives.
\end{abstract}

\section{Keywords:}

Reform, local administration, Algeria, administrative reform, financial reform.

JEL Classification: Z00 